\title{
THE SOUTH AFRICAN DEFENCE FORCE AND OPERATION HOOPER, SOUTHEAST ANGOLA, DECEMBER 1987 TO MARCH 1988
}

\author{
Gerhard J.J. Oosthuizen \\ North-West University (Potchefstroom Campus)
}

\begin{abstract}
The South African Defence Force (SADF) supported UNITA during Operation Modular (June to December 1987) to stop an extensive FAPLA offensive, known as Operation Saludando a Octubre ('Salute October'). FAPLA and its Cuban-Russian allies intended to eliminate the 'UNITA problem' once and for all, and they set the conquest of Mavinga and Jamba as their first target. The SADFUNITA alliance was, however, able to stop this advance during the Battle of the Lomba River (3 October 1987) successfully, and thereby achieved the first objective of Operation Modular. The remaining phases of Operation Modular (October to December 1987) were unsuccessfully aimed at the primary objective, namely to destroy the FAPLA brigades east of the Cuito River, or at least to force them west, across the Cuito River. The SADF-UNITA allies therefore agreed to continue military operations in the Sixth Military Region in an attempt to achieve this goal. After Operation Modular had formally come to an end early in December 1987, the planning of follow-up Operation Hooper was continued in all earnest. This article focuses on the claim of General Jannie Geldenhuys, head of the SADF (1985-1990), that Operation Hooper was an unqualified success and also on his controversial claim that Operation Hooper entered its last phase with successful attacks by the UNITA-SADF forces on 13 January, and 14 and 25 February 1988. Only the offensive/battle of 14 February 1988 was a success, however, and the SADFUNITA alliance was unable to destroy the FAPLA brigades east of the Cuito River or to force them across the river at least. Thus, once again, not all the objectives pursued after Operation Modular could be achieved. Within a period of approximately two weeks, two unsuccessful attacks were launched against Tumpoeach time from the same direction or line of approach. The FAPLA forces were very

Scientia Militaria, South African Journal of Military Studies, Vol 42, No. 2, 2014, pp. 84-116. doi : $10.5787 / 42-2-1095$

well entrenched and equipped, and they furthermore dominated the air. In contrast, factors such as inadequate intelligence (particularly regarding the second minefield and the death acres), insufficient military
\end{abstract}


equipment and manpower, inadequate logistics operations and the almost impassable sandy and bushy terrain hampered the SADF-UNITA attacks.

\section{Background}

The South African Defence Force (SADF) supported UNITA during Operation Modular ${ }^{1}$ (June to December 1987) to stop an extensive FAPLA ${ }^{2}$ offensive known as Operation Saludando a Octubre ('Salute October'). FAPLA and its Cuban-Russian allies were determined to eliminate the 'UNITA problem' once and for all, and they set the conquering of Mavinga and Jamba as the first goal in this process. The SADF-UNITA alliance, however, was able to stop this advance through a number of battles, which culminated in the Battle of the Lomba River (3 October 1987), and thereby accomplished the first objective of Operation Modular. Nevertheless, UNITA and the SADF were acutely aware of the fact that FAPLA would consolidate to launch another attack. The remaining phases of Operation Modular (October to December 1987) were unsuccessfully devoted to the primary objective, namely to destroy all FAPLA brigades east of the Cuito River, or at least to drive FAPLA west across the Cuito. The SADF-UNITA alliance therefore agreed to continue the military operations in the Sixth Military Region (Southeast Angola) in order to attain this objective. The SADF troop switch was completed on 9 December $1987 .{ }^{3}$ With Operation Modular then formally concluded the planning of the follow-up Operation Hooper could be continued in all earnest.

This article critically examines the claim made by General Jannie Geldenhuys, head of the SADF (1985-1990) that Operation Hooper was an "unqualified success", 4 and also the controversial claim made by Geldenhuys that -

The campaign ${ }^{5}$ entered its last phase [sic] with successful attacks [sic] by the Unita-RSA forces on 13 January, and 14 and 25 February 1988. The result was that all [sic] the forces that had participated in the enemy offensive were driven to the west of the Cuito River. ${ }^{6}$

In 1990, Lieutenant General AJ Liebenberg, head of the SA Army, confirmed the Geldenhuys claims that the RSA/SADF successfully accomplished its objectives in Southeast Angola. ${ }^{7}$ This article intends to present the 'real' state of affairs. 


\section{Preparation and planning by the SADF-UNITA alliance}

After the unsuccessful offensives by UNITA and the SADF on 25 and 26 November 1987, there was a period of planning of almost a month. FAPLA forces used this relatively quiet period to acquire logistic supplements and to entrench themselves well in three defence echelons (see Map 1 below). The FAPLA forces were convinced that the SADF-UNITA alliance intended to conquer Cuito Cuanavale and they wanted to prevent this at all costs. The first defence echelon was established between the Quatir and Chambinga Rivers, with the deployment of 21, 59 and 25 Brigade more or less in a north-south line. The second defence echelon stretched from the confluence of the Dala River and the Cuanavale River, across the Tumpo area to the convergence of the Chambinga River and the Cuito River. This echelon consisted of the Tactical Group, 66 Brigade and 16 Brigade. The third defence echelon was in the region of Cuito Cuanavale and consisted of 13 Brigade, a Cuban battalion, a divisional anti-aircraft brigade and a motorised Cuban infantry regiment. ${ }^{8}$

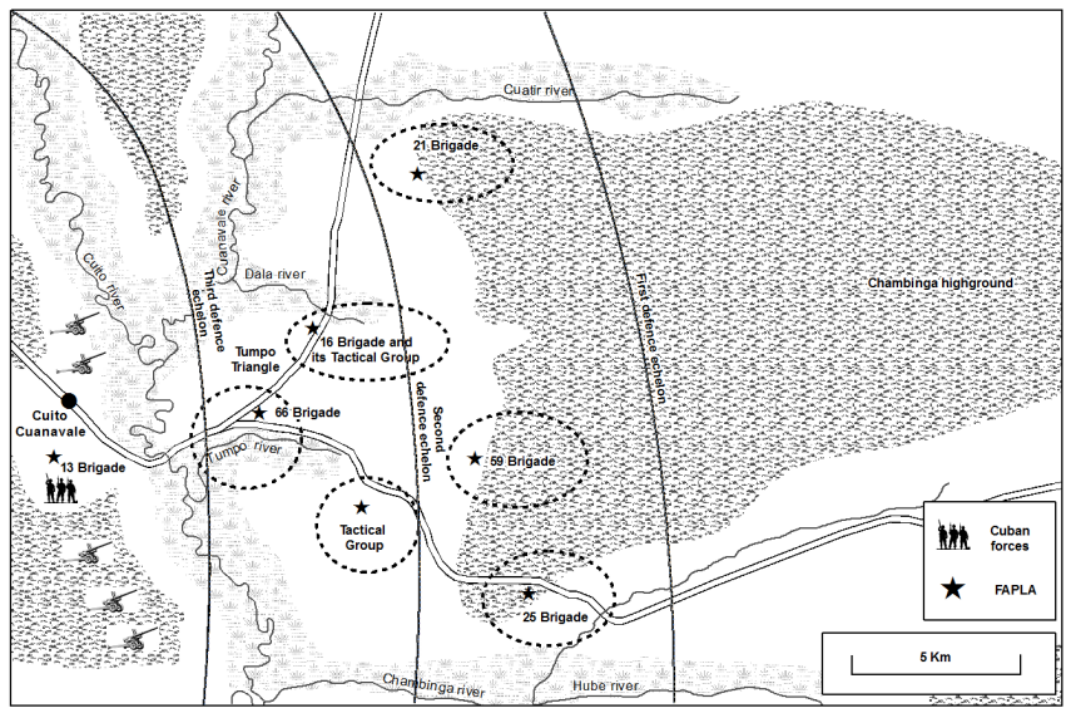

Map 1: FAPLA defence echelons east of Cuito Cuanavale, January $1988^{9}$

The SADF-UNITA planning was complicated by insufficient battle intelligence. As was the case with Operation Modular, UNITA intelligence was the main source of information; but time upon time this information proved to be unreliable and untrustworthy. This was especially the case with the identification of FAPLA forces, and with determining their strength and composition. The SADF 
therefore also used local artillery observers, the reconnaissance actions by 1 and 5 Reconnaissance Regiments and wiretapping of FAPLA radio networks. The SADF commanders and intelligence personnel had relatively accurate intelligence about the areas where the FAPLA forces were deployed, but sometimes there was uncertainty up to a very late stage of the deployment about the identification of FAPLA elements and the main equipment that would be used. The intelligence task of UNITA and the SADF was further complicated by FAPLA's constant patrolling of the region. ${ }^{10}$ Another serious obstacle was that the available maps were not up to date, and there were hopelessly too few maps available. Thorough planning was also hampered by a lack of aerial photographs. ${ }^{11}$ The following remark by Commander CS Harrison, SO1 Intelligence 20 SA Brigade, about this problem concerning intelligence, illustrates the situation:

Due to a total lack of photography and only the limited observation of arty Ops [artillery observation posts] and the account of one POW [prisoner of war] to plan on the analysis of the objectives will contain mostly appreciated int[elligence]. Appreciated or possible deployments etc will be indicated as such. ${ }^{12}$

While the planning was being done, UNITA and the SADF focused on harassment actions. The G5 cannons bombarded carefully selected targets almost every day, and FAPLA was powerless against it. Their artillery did not have nearly the same striking distance. Pressure was sustained, particularly on the FAPLA forces in Cuito Cuanavale and the surrounding region. The South African Air Force (SAAF) also participated in these harassment actions and in particular focused on the destruction of the Cuito Bridge. Logistic convoys of FAPLA were constantly disturbed by harassing fire and sting attacks, and so were the entrenched brigades in the different defence echelons. These continuous harassment actions negatively affected the morale of the FAPLA forces and made it impossible for them to move about freely during the day. ${ }^{13}$

Operational Instruction 33/87 finally came through on 11 December 1987. It contained the general battle design for Operation Hooper. The instruction was to destroy the FAPLA forces east of the Cuito River in cooperation with UNITA by 31 December 1987. The goal of Operation Hooper was to operationalise the objectives that could not be attained during the preceding operation successfully. In particular, it had to be ensured that FAPLA would not be able to launch another offensive from the Cuito Cuanavale area, at least for 1988. One of the guidelines determined that, if there was an opportunity to conquer Cuito Cuanavale with relative ease, plans had to be made to do so and to leave Cuito Cuanavale in the hands of UNITA. ${ }^{14}$ This instruction opened the way for further detailed planning to 
bring about the destruction of the FAPLA forces east of the Cuito River. A particularly difficult issue was how to limit SADF casualties to the absolute minimum and to mitigate the increasing local condemnation of SADF involvement in Angola.

By 20 December 1987, it was evident that UNITA and the SADF were not yet ready to launch a large-scale destructive offensive. Detailed planning was not yet finished, the equipment of the battle groups was not yet one hundred per cent operational, new troops still had to undergo essential training and drilling, and logistic stock was insufficient to support a large-scale offensive. ${ }^{15}$ There was, for example, a dire shortage of so-called 'bread-and-butter spares', and the poor operational condition of the artillery cannons was also a serious concern. ${ }^{16}$

UNITA officers were involved in a large-scale combined planning action only on 21 December 1987. The following day already, a preliminary broad battle design was compiled and circulated with a view to further refinement. The head of the South African Army was of the opinion that the action envisaged by the plan was too aggressive and that there was an extremely high risk of numerous casualties. He therefore laid down the guidelines that UNITA should be employed to start the attacks and that they should focus on only that goal at first. In addition, sufficient time had to be devoted to logistical supplementing, maintenance and repair of equipment and resting/relaxation of the troops. ${ }^{17}$ Operational Order 2/87 of 24 December 1987 stipulated that 20 SA Brigade had to drive 21 FAPLA Brigade from their positions and let UNITA occupy the area by 5 January $1988 .^{18}$

The lengthy planning and preparation for the next offensive also affected the discipline of the SADF soldiers negatively: a number of soldiers fired random shots and signal flares during the period 24 to 26 December 1987. Those who were caught, were disciplined strictly and the irresponsible conduct did not occur again. In the Brigade Administrative Area of 20 SA Brigade, equipment control, vehicle maintenance and vehicle control, as well as general control and supervision of personnel, hygiene and sanitation were not up to standard. The situation improved markedly after the implementation of a proper supervision plan as of 29 December 1987, however. ${ }^{19}$

Once the planning process had been completed, the SADF-UNITA alliance was finally ready to start the attack. However, the weather conditions would determine when the attack could start, as cloudy conditions were necessary because of the FAPLA air dominance. Furthermore, the unavailability of a number of G5 cannons would also be a restricting factor if they could not be repaired in time. ${ }^{20}$ 


\section{The same obstacle: 21 Brigade, 2 January 1988}

Sustained harassment actions, which were an outstanding feature of Operation Hooper, preceded the attack on 21 Brigade. The artillery concentrated on carefully selected targets in the Cuito Cuanavale area (and particularly the Cuito Bridge) and at brigade positions, as well as the airfields of Cuito Cuanavale and Baixo Longa. The SAAF and UNITA particularly concentrated on FAPLA convoys at Menongue and Cuito Cuanavale, but FAPLA forces reacted to this and harassed UNITA and the SADF with the dominating MiG fighter planes, and to a lesser extent also with D-30 artillery fire. ${ }^{21}$

The two main forces, namely 61 Mechanised Battalion Group (61 Mech) and 4 South African Infantry Battalion (4 SAI), were reinforced with UNITA's 3, 4 and 5 Regular Battalions, 18, 66, 275 and 118 Semi-Regular Battalions, and one socalled 'BIA (penetration) Battalion'. A regular battalion consisted of approximately 800 men, while approximately 300 men formed part of a semi-regular battalion. ${ }^{22}$

By 26 December 1987, 61 Mech and 4 SAI moved to their respective assembly areas. On the same day, the SAAF also launched attacks on 21 Brigade at 06:30 and 18:30, in accordance with the approved plan. Both attacks were followed by an artillery bombardment. Apart from the destruction of this brigade's SA 8 system, the SADF could not determine the effectiveness of the attacks. ${ }^{23}$

In the meantime, FAPLA tried in vain to monitor the positions and movements of the SADF-UNITA forces east of the Chambinga highland. The Advanced Command Post (ACP) of FAPLA therefore was mostly uninformed about the movements and plans of the SADF and UNITA. As a result, a reconnaissance force of 59 Brigade unexpectedly came into contact with SADF forces on 29 December 1987, and after heavy mortar fire, the FAPLA elements had to return to their brigade positions unsuccessfully. On the same day, UNITA also forced back a reconnaissance force of 25 Brigade, and 14 FAPLA soldiers died in the process. ${ }^{24}$

The approved plan included three possible phases. The first phase comprised psychological/propaganda actions aimed at persuading 21 Brigade to vacate their positions or to desert to UNITA, without a physical attack being necessary. If this were to fail, UNITA had to launch an attack, with the support of indirect SADF fire support. If necessary, phase 2 would be followed by an attempt by the SADF's main battle groups, $61 \mathrm{Mech}$ and $4 \mathrm{SAI}$, to conquer the positions of 21 Brigade. $^{25}$

Phase 1 was launched during the night of 30 December 1987 already, with the firing of propaganda grenades and the deployment of ground shouting teams. The latter shouted out propaganda messages in Portuguese over massive loudspeakers mounted on a military vehicle. UNITA manned the propaganda teams, 
while the equipment was operated by the SADF. The so-called 'psychological warfare' was aimed at breaking down FAPLA morale, and the message that was distributed on propaganda pamphlets was phrased with the help of UNITA: "FAPLA - You lose 267 comrades each day. You do not have to be next. Desert you have lost," and "We are going to murder you like 47 Bde [Brigade]. Do not be fools. Desert while you can." 26 However, these naive psychological operations had almost no effect on the FAPLA forces. Most of the FAPLA soldiers were illiterate and therefore unable to read the propaganda pamphlets. These pamphlets were also quickly destroyed by FAPLA.

The FAPLA-Cuban forces launched their own propaganda actions as well. Pamphlets with gruesome photographs formed the core of their propaganda, and a photograph of fallen Rifleman MH Smit and an SADF identity document was distributed along with the caption: "ANGOLA MAY BECOME YOUR GRAVE. Save your life. Refuse to fight. Go back." Another pamphlet contained the following message:

South African officers, sergeants and soldiers. You have been pushed to an uncertain and very dangerous adventure. You are facing up men who are well trained and they are ready to fight bravely. These men defeated your troops when you invaded the Angolan territory in 1975. At that time many of your compatriots died. Refuse to fight. Save your own life.

The initial shock, especially over the Smit photograph, quickly disappeared and was replaced by rage. ${ }^{27}$ Propaganda actions by both battle forces consequently contributed very little to breaking down the morale of the leader elements or the troops. To the contrary, the gruesome and graphical portrayal of the fallen comrades inspired the SADF members to fight the FAPLA-Cuban forces with even greater determination.

On 1 January 1988, 4 SAI progressed from the assembly area to the Fire Support Base (FSB). During this movement and set-up, the artillery regiment started its fire plan on the positions of 21 Brigade. The next day, at 02:00, 4 SAI bombarded FAPLA positions with tanks and $81 \mathrm{~mm}$ mortars. However, 4 SAI experienced no direct FAPLA fire while firing approximately 800 shots from the FSB. The FAPLA positions were also bombarded with approximately five hundred $81 \mathrm{~mm}$ mortars. Because the goal to force 21 Brigade from their positions through intense bombardment could not be accomplished, the SADF Tactical Head Quarters ordered 4 SAI to withdraw. This force reached its shelter at 07:45 without any incidents, and the vehicles were then camouflaged effectively. ${ }^{28}$ 
The pre-bombardment of the artillery regiment on the northern outpost of 21 Brigade was ceased early, according to plan, and the SAAF could then continue with an attack on 21 Brigade at approximately 06:00. After this air attack, UNITA attacked the northern outposts and experienced no resistance, because the position had been vacated. UNITA therefore focused on the southern outpost, but experienced heavy artillery fire from 16, 21 and 59 Brigades. Upon UNITA's request, the SADF then gave fire support, but in vain. UNITA conceded defeat, with severe casualties. The incessant bombardment and air dominance by the MiG fighter planes made it virtually impossible for the SADF-UNITA ground forces to launch any further attacks on 21 Brigade. The weather at the time favoured FAPLA to such an extent that the SADF abandoned its plan to launch another attack immediately. ${ }^{29}$ The constant threat by the Russian MiGs and the inability of the SAAF to overcome it severely traumatised the SADF and UNITA soldiers. This threat was also one of the major causes of post-traumatic stress syndrome experienced by members of the SADF. ${ }^{30}$ The journal entry by C Holt on 11 December 1988 gives the following description of this situation:

It is actually quite frightening when you hear that bastard [MiG] going over ... To be honest, I haven't experienced this kind of fear before; this was the first time my legs actually trembled and I started sweating through fear. ${ }^{31}$

This unsuccessful SADF-UNITA attack clearly proved that UNITA could not conquer the well-entrenched FAPLA positions without the active support of the SADF mechanised forces. In fact, this lesson had already been learned during Operation Modular, but the SADF and UNITA nevertheless made the same mistake. The determination of the FAPLA forces to defend the area east of the Cuito River also meant that it would not be possible to conquer the FAPLA positions without a well-planned mechanised attack, together with heavy artillery firing support and bombardments against the FAPLA artillery. Furthermore, careful deliberation was necessary regarding the use of UNITA as an infantry shield force. The way in which the MiGs restricted the SADF artillery made FAPLA's artillery power an important factor, as it could result in serious casualties in future. ${ }^{32}$

\section{Success and failure go hand in hand: 21 Brigade, 13 January 1988}

The time lapse between the first and second attacks on 21 Brigade was characterised by attacks on the Cuito Bridge, deceptive actions, harassment actions and continuous bombardment of carefully selected targets by among others the G5 cannons and the SAAF. FAPLA, on their part, severely obstructed the SADFUNITA actions through the MiG fighter planes. ${ }^{33}$ 
In the interim period, the destruction of the Cuito Bridge was a high priority. Up to that stage, the SADF artillery could not succeed in rendering the bridge unusable, in spite of continuous firing. On 12 December 1987 already, the SAAF made an unsuccessful attempt to destroy the bridge with an $\mathrm{H} 2$ bomb. The effective destruction of the bridge would have severely obstructed the logistical provision and reinforcement of 21 Brigade. At 07:44 on 3 January 1987, two Buccaneers and four FIAZ Mirages proceeded to the target from Grootfontein. The presence of MiG fighter planes in the air space above the Cuito Bridge, however, forced the SAAF fighter planes to turn back unsuccessfully south of Mavinga. ${ }^{34}$ The SAAF made another attempt at 11:40, but while the SADF airplanes approached the Cuito Bridge, two MiG-23 fighter planes attempted to cut them off. The FAPLA fighter planes unexpectedly and inexplicably stopped the pursuit and returned to Menongue, however. The SAAF thereupon proceeded with the attack and hit the bridge at 12:31. Approximately 20 metres of the bridge were totally destroyed, meaning that until it could be repaired, FAPLA would not be able to use the bridge for transporting personnel or equipment across the river. Attempts to repair the bridge were particularly delayed by constant bombardment by the SADF's G5 cannons. ${ }^{35}$ FAPLA, however, had modern river crossing and bridge construction equipment and they were therefore not dependent on the existing bridge. Eventually, though, the partial destruction of the Cuito Bridge and the time it took to repair the bridge had very little effect on the further progress of Operation Hooper.

Before the next attack on 21 Brigade, the SADF-UNITA alliance launched interim deception actions. These involved, amongst others, mock bridge construction activities across the Cuito River and the deployment of mock artillery positions. These were intended to bring the FAPLA forces under the impression that an attack was being planned from the southwest after the Cuito River had been crossed. In the meantime, the SAAF and the SADF-UNITA artillery continued to bombard carefully selected targets. FAPLA, on their part, also harassed UNITA and the SADF with air attacks and artillery bombardments. Although active FAPLA air domination considerably obstructed the movement of the SADF mechanised forces, the devastating artillery fire of the SADF caused a morale crisis for the Angolan soldiers, and many of them deserted because of this. ${ }^{36}$

Eventually the Commanding General of the South-West Africa Territorial Force (CG SWATF) ordered that D-day had to take place by 13 January 1988 at the very latest. However, he determined that - irrespective of the weather conditions the target had to be approached at night as far as possible, together with the effective use of anti-aircraft weapons. ${ }^{37}$ Thus, FAPLA had to be prevented from using the MiGs as far as possible, so that the SADF-UNITA forces could have maximal freedom to operate. 
During the night of 11-12 January 1988, the SADF-UNITA forces were ready for the attack on 21 Brigade. On this occasion, 4 SAI and 3 Regular Battalion of UNITA acted as the main strike force, while 61 Mech had to act as a cut-off force and mobile reserve to prevent any interference by FAPLA elements from the south or from Tumpo. Due to bad weather conditions, however, D-day had to be postponed until the next day. The planned SAAF attack on the positions of 21 Brigade took place at 09:45. The SADF artillery then launched prebombardments on the southern and northern outposts, while $120 \mathrm{~mm}$ mortars were fired at the positions of 21 Brigade and 59 Brigade. With the approach towards contact on the southern outpost, 4 SAI was bombarded by a BM-21, upon which the SADF artillery responded with a counter-bombardment. Because FAPLA did not offer much resistance, the southern outpost was easily conquered. Then 4 SAI and 3 Regular Battalion of UNITA moved in together on the northern outpost. Strong resistance was experienced at this outpost, particularly against UNITA foot soldiers. By 15:50, after severe fighting, the last of the 21 Brigade soldiers vacated the outpost and retreated to the main positions or fled. ${ }^{38}$ Thus, this target was also conquered in its entirety by the SADF-UNITA forces.

The advance towards the primary target, namely the main positions of 21 Brigade, was temporarily interrupted by a FAPLA air threat. After fierce contact for 58 minutes, the resistance of the FAPLA force was broken. As it got darker, FAPLA could not sustain the resistance from the air, and the remaining elements of 21 Brigade fled. By 23:15, the main positions of 21 Brigade had been vacated and were now occupied by 3 Regular Battalion. The next day, a battle team of 4 SAI remained behind at the positions of 21 Brigade to support UNITA with the vacating process. The rest of the battle forces moved towards their encampment area for supplements, maintenance and repairs. ${ }^{39}$ The decision by the SADF to trust UNITA with most of the occupation and defence of the conquered positions of 21 Brigade was, however, a tactical mistake, which the FAPLA forces would fully exploit.

The second attack was indeed a clear success for the SADF-UNITA alliance. The combined attack by 4 SAI and 3 Regular Battalion especially proceeded excellently. FAPLA lost 150 soldiers and a vast amount of military equipment, while only four UNITA soldiers died and the SADF lost no lives or equipment. ${ }^{40}$ However, as was the case in the previous attacks, the SADF-UNITA forces did not sustain the momentum and the advance of the SADF-UNITA strike force was once again interrupted by FAPLA air threats. This enabled the FAPLA forces to consolidate and to bring in essential reinforcements. W Dörning, military historian of the SADF, concludes about this situation that the absolute inability to defend RSA ground forces against enemy air attacks was once again apparent, and that it was clear that in future the enemy could employ its air force at crucial times to 
thwart RSA successes, and that with more accurate air attacks it would be possible for the FAPLA air force to cause serious casualties to the RSA ground forces. ${ }^{41}$

While UNITA and the SADF planned further attacks on the FAPLA defence echelons, the FAPLA commander of the 6th Military Region was determined to take back the 21 Brigade positions. UNITA already learned about this through wiretapping on 16 January 1988. Therefore 4 SAI was tasked to prevent any reconquering attempts. A battle team of 4 SAI was also placed on stand-by in case FAPLA were to attack from the southwest. ${ }^{42}$ FAPLA's 8 Brigade was ordered to support 21 Brigade to take back the positions. On 17 January 1988, the combined force took the temporary positions on the high ground in the vicinity of the source of the Dala River. After UNITA had seized the necessary equipment, they withdrew from their positions out of fear of FAPLA artillery fire and deployed east of the positions. This made it possible for the reinforced Brigade 21 to take back its positions - almost without any resistance - on 18 January 1988. Then 8 Brigade left for Cuito Cuanavale to resume its service as a convoy defender. ${ }^{43}$

The question remains why the battle team of 4 SAI made no attempt to prevent the re-occupation of the positions by 21 Brigade. In the war journal of 20 SA Brigade HQ, it is simply stated, with no reasons being given, that it was decided not to launch any action by South African forces. The reader is then simply referred to Addendum D, where it is expressly stated that the battle team of 4 SAI had to force FAPLA forces to the south of the Dala River and/or destroy them. It is also emphasised that the battle team should not get involved in decisive battles and that the attack should be carried out in cooperation with 3 Regular Battalion of UNITA. $^{44}$

The most important reason why the SADF allowed 21 Brigade to re-occupy their positions was probably a tactical one. If FAPLA could be deployed on a familiar target and terrain, it would have been possible to attack the FAPLA forces in relative isolation. Dörning further explains that it was easier to attack and destroy a hostile force in the first defence echelon than to attack the same force together with other hostile forces in the fortified Tumpo area, where much more accurate artillery support could be given to the enemy. ${ }^{45}$

The re-conquering of the positions by 21 Brigade totally demoralised the SADF troops and made them very negative towards UNITA. Major General Willie Meyer (CG SWATF) therefore urgently requested all SADF commanders to explain that, because of their weaponry, UNITA was no match for the FAPLA tanks. It also had to be emphasised that the enemy sometimes had to be allowed to re-occupy their former position, so that they could be destroyed during a subsequent attack. ${ }^{46}$ 
The psychological action plan of the SADF was specifically aimed at constantly indoctrinating the leadership and particularly the national conscripts. From 19 December 1987 chaplains regularly had to convey a number of propaganda themes, such as

- $\quad$ UNITA being an important force to stop Soviet imperialism in Africa;

- $\quad$ Angola being used by the USSR as a firm base to take over the Republic of South Africa (RSA);

- $\quad$ The ability of the RSA to win being demonstrated to friend and foe;

- $\quad$ The men behind the Russian devilish weapons being ungodly and corrupt;

- $\quad$ Supporting UNITA to free the people of Angola;

- Helping UNITA to make Angola a bastion of Christ; and

- $\quad$ Being soldiers of Christ. ${ }^{47}$

The chaplain plan of Operation Hooper made provision for sermons before and thanksgiving services after offensives, and the service on Sunday 27 December 1987 had to be aimed at the preparation for the attack on 21 Brigade. $^{48}$

The re-occupation of the positions of 21 Brigade meant that the breach that was made in the first defence echelon had been filled again. A planned attack on 59 Brigade and 25 Brigade from the north could therefore only be undertaken after the re-conquering of the positions.

\section{Success at last: 59 Brigade, 14 February 1988}

On 16 January 1988, the broad battle design was planned for 20 SA Brigade. The battle design determined that two main actions would take place, namely the attack on 59 Brigade and 25 Brigade, upon which an attack would be launched on Tumpo and the tactical group. ${ }^{49}$ The re-occupation of the positions by 21 Brigade, however, obstructed these plans, and therefore the SADF, in deliberation with UNITA, had to make considerable adaptations.

The adapted battle design, dated 24 January 1987, determined that 59 Brigade would be the primary focus of the attack. The rationale for this decision was among others the fact that the SADF and UNITA had relatively accurate information about the set-up and composition of the brigade. Furthermore, this brigade was regarded as the strongest unit in the first defence echelon of FAPLA. Its destruction would therefore negatively affect FAPLA's defence. The commanders of the Angolan 6th Military Region therefore had to reinforce the defence of Tumpo considerably by, among other actions, moving 21 Brigade and 25 Brigade as reinforcements to this area. A combined attack by the SADF and UNITA, protected by a flank force in the west, would be launched from the north. D-Day was preliminarily set for 28 January $1988 .^{50}$ General Jannie Geldenhuys, head of the 
SADF, further determined that, before the SADF would withdraw from Angola, three goals had to be achieved:

- $\quad$ FAPLA had to be driven to the west of the Cuito River;

- Cuito River had to be established as an obstruction; and

- UNITA had to be enabled to act independently.

The latter objective implied that UNITA had to receive intensive training in the use of tanks. ${ }^{51}$

The many postponements of the attack on 59 Brigade gave the FAPLA forces the opportunity to reinforce trenches and bunkers east of the Cuito River. The logistics route between Menongue and Cuito Cuanavale was also very busy as new equipment and stock were being transported to the forces. ${ }^{52}$ During the planning, the SADF concentrated on the almost incessant bombardment of carefully selected targets. $^{53}$

D-day was constantly postponed because the SADF-UNITA forces had to wait for cloudy weather to restrict the air domination by the MiGs and due to logistic inadequacy. For example, there was a constant lack of essential parts, which limited the use of the G5 cannons. ${ }^{54}$ By 7 January 1988, the situation was so bad that eight of the 22 tanks broke down due to mechanical problems while the encampment of Battle Group C (4 SAI) was being moved. All the tanks were recovered, but some would not be ready to be deployed during the next offensive, unless indispensable parts could be received. Apart from that, there was also a dire shortage of diesel filters for the B vehicles. ${ }^{55}$ During Operations Modular and Hooper, a delay was experienced after literally every attack, primarily because of logistical problems.

The inadequate logistical supplies of the SADF not only delayed offensives, but also negatively affected the morale of the troops. Upon a request by medical personnel, for example, Tactical Head Quarters approached Brigade Head Quarters in Rundu to supplement the dry rations of the troops at the front with fresh food and vitamins as soon as possible. Some of the SADF soldiers received fresh meat for the last time at Christmas 1987. This state of affairs was not only demoralising but of course also detrimental to the troops' health. ${ }^{56}$

To make matters worse, a jaundice epidemic and to a lesser extent a malaria epidemic $^{57}$ broke out among the troops, and 106 soldiers of 4 SAI had to be evacuated. These evacuations caused great concern about the battle readiness of 4 SAI and it also had an extremely negative effect on the morale of the soldiers. ${ }^{58}$ One mechanised platoon, for instance, could not be deployed, because the platoon commander, the platoon sergeant, four section commanders and three section second-in-commands had to be evacuated because of jaundice. Certain vehicles also 
could not be used effectively because of a shortage of drivers. ${ }^{59}$ Furthermore, the commanders of 4 SAI (Commander Jan Malan) and 61 Mech (Commander Koos Liebenberg) contracted jaundice ${ }^{60}$ and had to be replaced, respectively by Cassie Schoeman and Mike Müller. Only a few weeks after that, Schoeman also had to be replaced as commander, because of a heart attack. This health situation adversely affected the SADF manpower situation, and UNITA was therefore required to perform certain tasks for which they were not initially responsible. ${ }^{61}$ Shortages of, among others, indispensable Ratel parts, and the inoperativeness of $50 \%$ of the G5 cannons also delayed the attack on 59 Brigade. $^{62}$

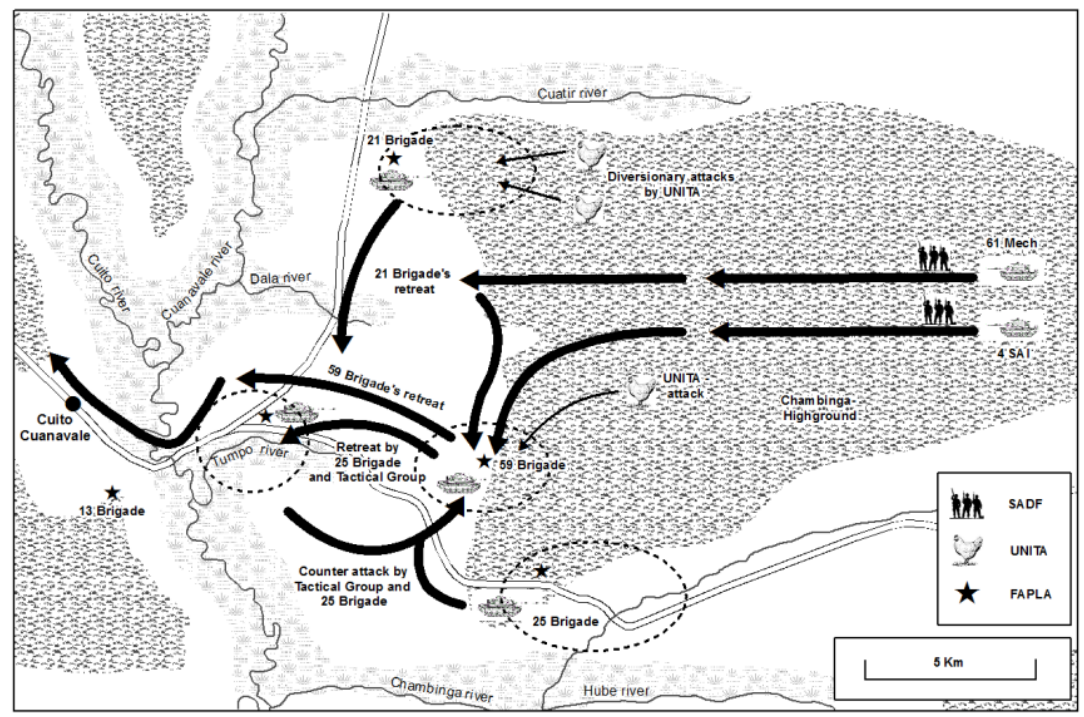

Map 2: SADF-UNITA attack on 59 Brigade, 14 February $1988^{63}$

The battle plan made provision for $4 \mathrm{SAI}$ attacking the main positions of 21 Brigade. This would be preceded by sting attacks on the eastern positions of this brigade. Thereupon 4 SAI had to start with an attack on 59 Brigade from the northwest, but only after UNITA had attacked the eastern positions of the brigade. Due to medical losses because of jaundice and malaria, which affected 61 Mech in particular, it was decided that UNITA would be responsible for the attack on 21 Brigade. To prevent possible interference from Tumpo, for instance, $61 \mathrm{Mech}$ was deployed as a reserve force, together with a flank force, south of 21 Brigade. SADF-UNITA deception actions misled the FAPLA forces to such an extent that the ACP in Cuito Cuanavale was convinced that 21 Brigade was the main target. As a result, 21 Brigade was considerably reinforced, to the detriment of 59 Brigade. 
Then 59 Brigade tried in vain to convince the ACP (see Map 2 below) that they would also be attacked and that they would not be able to fend off a SADF-UNITA onslaught under those circumstances, but the ACP insisted that the main target was 21 Brigade. $^{64}$

On 14 February 1988, the SADF and UNITA were all set for the attack. At 14:50, UNITA launched simultaneous attacks from the north and the south on the positions of 21 Brigade. At the same time, a UNITA battalion and 4 SAI also launched attacks from different fronts on the positions of 59 Brigade. The simultaneous attack on two fronts by UNITA and the SADF caused great panic and disorder. Because of the panic in the main positions of 59 Brigade, for example, some of the FAPLA troops fled headlong in the direction of Tumpo. The SADFUNITA alliance was able to conquer the positions of 21 Brigade and 59 Brigade comfortably. During the night of 14-15 February 1988, the two brigades escaped to the Tumpo area. Under orders of the ACP, 25 Brigade also withdrew to the Tumpo area early in the morning of 15 February $1988 .{ }^{65}$

A counter-attack that was planned and led by Cubans was more problematic, however. Repeated requests by 59 Brigade finally paid off when 25 Brigade, reinforced with tanks from Tumpo, was ordered to support 59 Brigade. Thus, 61 Mech immediately moved southward, together with 4 SAI, to face the FAPLA counter-offensive. At 18:25, FAPLA started bombarding 61 Mech with accurate artillery fire and hit one of the Ratels. Furthermore, the artillery was adjusted accurately as the SADF force moved, and the attack was followed almost immediately by tank fire from the west, south and east. The FAPLA tanks were aggressive and acted boldly. The tanks were also constantly supported by FAPLA artillery, and in the process, another Ratel 20 and one tank were hit. In response, the SADF started a fierce counter-attack, and in the process, they destroyed seven FAPLA tanks and numerous vehicles. Upon this, the FAPLA force ceased the counter-attack and withdrew to Tumpo. At 19:05, 4 SAI, 61 Mech and UNITA elements were ordered to withdraw, because it was already too late in the day to pursue FAPLA. $^{66}$

During the afternoon of 15 February 1988, a FAPLA relief force departed from Tumpo to re-occupy the conquered positions of 59 Brigade. This second counter-attack, however, was also successfully fended off by a combined SADFUNITA force. In contrast with the first attack on 21 Brigade, FAPLA was not allowed to resume their old positions. With this FAPLA defence line also being eliminated, Tumpo was the only remaining defence line east of the Cuito River. ${ }^{67}$

On the SADF side, four soldiers died, while six had to be evacuated due to injuries, one due to a heart attack and two due to shock. Three Ratels and one 
Olifant tank were also lost. ${ }^{68}$ The FAPLA forces lost a total of 15 tanks, numerous other vehicles and an unknown number of soldiers. However, the success was not directly followed up, because the commanders of 4 SAI and 61 Mech indicated to HQ Rundu that they were not prepared to continue the attack on Tumpo immediately. ${ }^{69}$ Thus, the initiative was not exploited by the SADF-UNITA forces, and the FAPLA forces were once again able to consolidate and reinforce their position.

\section{Achilles heel: Attacks on Tumpo, 25 February and 1 March 1988}

With the partial conquering and subsequent collapse of the second FAPLA defence echelon on 14 February 1988, the Tumpo area was the last remaining FAPLA position east of the Cuito River. At that stage, it was a high priority for FAPLA to retain this key area. Control over the Tumpo area would mean that they would be assured of a bridgehead across the Cuito River, without which they would not be able to launch a future attack on UNITA. Furthermore, control of the area would effectively prevent the SADF-UNITA alliance from attacking Cuito Cuanavale. For the SADF-UNITA forces, on the other hand, the conquering of the Tumpo area meant that their orders to destroy all FAPLA forces or to force them west of the Cuito River would eventually be accomplished. FAPLA control of the Tumpo area would also imply that FAPLA would still have a bridgehead and that the conquered areas would certainly be re-occupied if the SADF were to withdraw. With UNITA in control of the key area in the region of Tumpo, a new FAPLA offensive against the UNITA positions of Jamba and Mavinga would have had to be postponed. $^{70}$

The Tumpo area was a well-planned defence system. Infantry positions, supported by tanks, anti-tank and indirect weapons, covered almost all possible access routes from the north, east and south. There were also anti-tank and antipersonnel minefields ahead of the positions. These minefields were covered by, among others, the FAPLA artillery. Furthermore, the high ground of the west bank of the Cuito River benefited FAPLA, because it made direct observation of almost the entire Tumpo area possible and it offered excellent artillery fire support to the east bank. Logistics could also be provided with almost no obstructions. ${ }^{71}$ Without intensive and creative planning, the SADF and UNITA would not have been able to achieve success in these circumstances.

By 17 February 1988, the battle groups were gathered in their encampment areas and the necessary repairs and logistic supplements were made. While the planning was being done, the SADF artillery and the SAAF were again urged to sustain pressure on the FAPLA forces. UNITA also participated in the harassment actions and launched sting attacks on Tumpo, among others. Attacks particularly 
focused on logistics convoys on their way to Cuito Cuanavale. MiG fighter planes consequently gave air cover to FAPLA convoys and also attacked SADF convoys. ${ }^{72}$ As usual, MiGs dominated the air and continuously brought the SADF-UNITA movements to a standstill. The MiG danger was clearly demonstrated in an attack on 21 February 1987, during which three SADF soldiers died and one was seriously wounded. $^{73}$

The approved attack plan (OPSO 2/88) that was issued on 22 February 1988 included the general order that 20 Brigade, in cooperation with UNITA, should destroy the enemy in the Tumpo area and/or force them west of the Cuito River, and UNITA had to occupy the area as soon as possible. ${ }^{74}$ The main strike force, under the command of Commander Mike Müller, consisted of 61 Mech, supported by one tank squadron of 4 SAI, 32 Battalion and 3 and 5 Regular Battalions of UNITA. The flank force was under the command of Major S Lötter, while 4 SAI, under the command of Commander Cassie Schoeman, served as a reserve force. ${ }^{75}$ However, at 22:10 on 24 February 1988, Schoeman had to be evacuated urgently because of a heart attack. He was replaced by his second-in-command. ${ }^{76}$ In accordance with the planning guidelines prescribed by Tactical HQ Rundu to Colonel PJ Fouche, commander of 20 SA Brigade, the maximum number of UNITA foot soldiers would be employed during the attack, primarily to draw fire and to establish targets. ${ }^{77}$ This illustrates the way in which the SADF persisted with their tactic to use UNITA as a buffer in an attempt to limit SADF casualties to the minimum. This tactic increased UNITA's mistrust of the SADF, because they felt that they were being used as "cannon fodder".

Just after 04:00 on 25 February 1988, 32 Battalion attacked the south-eastern FAPLA positions, while UNITA launched a sting attack on the north-eastern positions of FAPLA's front defence line. The SADF-UNITA main force that moved in for the attack was caught in a protection minefield. Four SADF tanks were stuck there and were out of action for the rest of the battle. The detonation of a landmine by a tank brought the main force to a stop and informed FAPLA of the direction from which the SADF-UNITA main force was about to attack. While FAPLA harassed the main force with heavy artillery fire, the SADF was able to breach the minefield after an immense effort. The front elements of the main force were able to move through the lane, but were confronted with heavy artillery fire. The rest of the strike force was held back by a heavy FAPLA air threat, which prevented them from moving through the minefield. Despite the threat, the main force was eventually able to pass through the minefield and to join 32 Battalion. The combined force then moved towards the south-eastern targets. Because the strike force moved through an almost open area, the FAPLA air force and artillery intensified their attacks. During the attacks, a number of tanks, Ratels, Ystervarks and logistic vehicles were 
damaged. A considerable number of UNITA soldiers died and 12 SADF soldiers had to be evacuated (nine who were wounded and three because of stress). Because of the continuous air threat and accurate artillery fire, Commander Mike Müller planned to withdraw. However, HQ Rundu asked Müller to withdraw only temporarily and to consider continuing the attack in a westerly direction. Müller responded that, because of FAPLA's accurate artillery fire, this would not be possible. Increasing personnel and vehicle losses eventually forced the SADFUNITA forces to withdraw shortly after 18:33. ${ }^{78}$

The order to destroy the FAPLA forces east of the Cuito River or to force them west of this river could therefore not be accomplished. In fact, the FAPLA defence positions were exactly as they were before and FAPLA was firmly in control of the Tumpo key area. Numerous factors thwarted the SADF-UNITA assault, but the most important obstruction was the air domination by FAPLA. During the assault on Tumpo, the FAPLA air force undertook 59 sorties, with the effect that they were almost incessantly in the air for the duration of the assault. This obstructed the advance of the main force. Because of FAPLA's air dominance, the SAAF could not offer effective air support to the ground forces and the SADF artillery was restricted to such an extent that effective counter-bombardments and bombardments of carefully selected targets became impossible. FAPLA's morale was high, because the SADF-UNITA assault had been fended off without involving the FAPLA tanks and troops in a direct contact. ${ }^{79}$

Shortly after the attack of 25 February 1988, the SADF again launched ground shouting actions under command of Commander Les Rudman. The propaganda themes were compiled in cooperation with UNITA and were shouted out in Portuguese over massive loudspeakers, and were aimed at encouraging the enemy to desert and to increase their frustration and demoralisation. UNITA and the SADF were unable to determine the effectiveness of the campaign through wiretapping, ${ }^{80}$ but it can be assumed that the morale of the FAPLA forces would have been very high after they had just fended off an SADF-UNITA assault successfully, and that the propaganda actions would have been mostly ineffective.

During the planning of a second attack on Tumpo, the SADF-UNITA alliance had to take into consideration four factors in particular, and of these, the neutralisation of the FAPLA artillery and air domination was the most important. The strike force also had to be able to breach minefields quickly and effectively, and thorough reconnaissance and sweeping of access routes (to locate landmines and anti-personnel mines) were also priorities. It was indicated that the latter should take place just before the attack, but preferably before the advance of the strike force. ${ }^{81}$ 
The period between the first and second attacks again gave the opposing forces an opportunity for the necessary planning and logistical supplementing. After the attack of 25 February 1988, 25 Brigade, 59 Brigade and the Tactical Group remained behind in the Tumpo area. Their ranks were later reinforced with weapons and personnel. SADF-UNITA intelligence indicated an unsettling increase of Cuban involvement in the defence of the Tumpo area. ${ }^{82}$

After various deliberations between delegates of UNITA and the SADF, the battle design for the next attack on the Tumpo area was approved. According to OPSO 3/88, the general order involved that 20 Brigade had to destroy FAPLA at the bridgehead east of Cuito Cuanavale, or drive them west of the river and then destroy the bridge. Meanwhile, $61 \mathrm{Mech}$, under the command of Commander Mike Müller, was the main strike force and was supported by 3 and 5 Regular Battalions of UNITA, 32 Battalion, one tank squadron and one engineer section. A bridgedamaging team and a reserve force were also part of the second SADF-UNITA assault on the Tumpo area. Elements of 4 SAI formed part of the reserve force and also had to perform deception and shielding tasks. ${ }^{83}$ The order was very similar to the order of the first attack on Tumpo, but with two obvious differences: there was no mention of the cooperation with UNITA, and the destruction of the Cuito Bridge was specified as a particular objective.

On 29 February 1988, 61 Mech started with the advance, and reached the pre-assembly area at 17:37. Due to a dire shortage of operative tanks, the force had only ten battle tanks. The driver periscopes of five of the tanks were out of order, with the result that the tank drivers could not see where the tanks were moving in open formation. The ranks of the tanks were reinforced by nineteen Ratel 90s. The 20 SA Brigade Commander and the commanding general of the South West African Territorial Force in Rundu enquired from Commander Müller whether he was willing to proceed with the attack regardless of this shortage of tanks. Müller indicated that they had to go ahead. ${ }^{84}$

Bad weather conditions severely restricted visibility, and the planned night attack was moved to daybreak of the next day, upon Müller's request. The advance started at 05:45, and 5 Regular Battalion of UNITA joined the main strike force approximately three hours later. The low and dense cloud mass was to the advantage of 61 Mech, because it restricted the FAPLA air threat. The strike force moved slowly and by 12:00 it was bombarded by approximately ten $23 \mathrm{~mm}$ cannons. To avoid the weapons, Müller turned towards the south and then moved in the direction of the target. About two hours later, a mine roller detonated a number of personnel mines, whereupon the strike force was again bombarded with $23 \mathrm{~mm}$ cannons and also with $120 \mathrm{~mm}$ mortars. Müller responded with $81 \mathrm{~mm}$ mortar fire. Shortly 
thereafter, an SADF tank detonated an anti-tank mine. At that stage, FAPLA brought down intensive anti-tank fire from three sides on $61 \mathrm{Mech}$. The strike force had inadvertently moved into the slaughter area or acre of death, which was covered at the front and at both flanks by anti-tank weapons and $23 \mathrm{~mm}$ cannons, with artillery fire support from the west bank. The strike force also moved into a highdensity minefield that was littered with anti-personnel mines and anti-tank mines. After another three tanks detonated mines, the strike force retreated slightly. Shortly afterwards, heavy firing broke out between the two opposing forces, lasting for approximately 45 minutes. The strike force, however, could not neutralise the $23 \mathrm{~mm}$ cannons and $120 \mathrm{~mm}$ mortars of FAPLA. ${ }^{85}$

The heavy FAPLA firing forced the attacking force to withdraw further gradually. Quite a number of SADF vehicles broke down due to mechanical problems and FAPLA also persistently bombarded the strike force with $23 \mathrm{~mm}$ cannons. Müller therefore decided to withdraw to a safe area with a view to reorganising. During the withdrawal and amidst severe and persistent $23 \mathrm{~mm}$ cannon fire, two Ratel 90s were hit. When the strike force was beyond the maximum reach of the $23 \mathrm{~mm}$ cannons, HQ Rundu enquired from Müller whether he would be willing to launch a night attack together with 32 Battalion. Müller declined to do so, because only five of the ten tanks could be deployed operationally at that stage. The second attack on Tumpo was then called off, and 61 Mech and 4 SAI withdrew to their respective assembly areas to focus on maintenance and repairs. ${ }^{86}$

A battle team of 4 SAI remained behind with UNITA, however, to prevent FAPLA from re-occupying the conquered positions of 59 Brigade. Commander Rudman and his team, supported by multi-rocket launchers, also harassed the FAPLA positions with ground shouting actions on 2 March 1988, from 21:00 onward. The message urged FAPLA to leave their positions and to go to the west bank, or to face death. By 03:00, these actions were stopped because the equipment broke down. UNITA intelligence informed the SADF that the propaganda reached the target area and that it caused visible distress. ${ }^{87}$ However, the UNITA report is questionable and it may be assumed that, just as in the past, the ground shouting action had no significant effect.

The attacking force was outmanoeuvred by FAPLA and eventually had to withdraw without any success. Once again, the order to destroy all FAPLA forces east of the Cuito River or to force them west of this river could not be accomplished. All Tumpo positions were still occupied and FAPLA was still firmly in control of the east bank. Launching an attack with only one tank squadron, of which five tanks were not even operative, was virtually insane. A familiar and indisputable fact was again confirmed, namely that Ratel 90s or similar military vehicles could not replace 
tanks in a conventional battle. The second failed attack was very demoralising for the UNITA and SADF troops, and in response to this, deliberate actions were launched to convince the troops that the SADF-UNITA forces had not lost against FAPLA. The FAPLA forces, and the Cubans in particular, saw the failed assaults on Tumpo as massive victories and announced far and wide that the SADF and UNITA had been defeated at Cuito Cuanavale. ${ }^{88}$

Early in March 1988, 4 SAI and 61 Mech were in their respective assembly areas, busy with repairs and maintenance of equipment, and with demobilisation planning. Until the exchange of troops would take place, whereupon a new operation would be launched, interim actions were planned and performed to sustain pressure on the FAPLA forces. The first elements that formed part of the troop exchange action had already arrived at the front on 5 March 1988. On 12 March 1988, the formal hand-over between the staffs of 20 SA Brigade and 82 Brigade took place, and thereafter the Tactical HQ of 82 SA Brigade started planning the third attack on Tumpo. Operation Hooper was formally ended with the departure of 20 SA Brigade's Tactical HQ the next day. ${ }^{89}$

\section{Conclusions}

Claims by General Jannie Geldenhuys that Operation Hooper was an unqualified success and that all offensive FAPLA brigades were forced west of the Cuito River were completely inaccurate. In spite of being vastly outnumbered, though, the SADF-UNTA alliance did achieve significant successes. At most, Operation Hooper may therefore be described as having achieved qualified successes. The first defence echelon was conquered in its entirety after two combined attacks by UNITA and the SADF. Thereafter, a part of the second echelon was conquered, and the FAPLA forces then gathered in the area around the Cuito Bridge known as Tumpo. FAPLA was convinced that the SADF and UNITA intended to occupy the key area in order to conquer Cuito Cuanavale. The area was therefore developed into a formidable stronghold and the SADF and UNITA could not succeed in conquering it, in spite of two fierce attacks.

The two failed assaults on Tumpo negatively affected the morale of the SADF and UNITA troops. In contrast, the morale of the FAPLA forces was raised, and Cuba in particular used these failures maximally for international propaganda. Excessive claims were made, such as "... up to 6000 SA motorised infantry troops backed by armoured cars, tanks and long range G-5 and G-6 (sic) cannon" being involved in the "battle" for Cuito Cuanavale. It was also alleged that no fewer than forty SADF airplanes were shot down during the assault on Cuito Cuanavale. ${ }^{90}$ Consequently, international condemnation of the presence of the SADF in Angola drastically increased. 
The SADF followed a pattern of withdrawing shortly after an attack and thereby they constantly lost the initiative. This enabled the FAPLA forces time and again to recover almost unrestrictedly, to obtain logistic supplements and to acquire personnel and equipment reinforcements. Colonel Roland de Vries therefore points out that it was a bitter reality for him that they had lost their initiative or freedom to act because there simply was not enough momentum: there were too few forces available and logistics almost functioned according to a type of crisis management. ${ }^{91}$

During the SADF reflection conference, the opinion about the FAPLA air dominance was unanimous. The troops were very frustrated about the incapability of the SADF-UNITA anti-aircraft systems. The air threat greatly affected the morale of the troops and some of them openly admitted that they were scared of the MiG fighter planes. ${ }^{92}$ The enemy air dominance restricted the freedom to act of the SADF-UNITA forces in particular and they were often forced to act at night or to be stationary for long periods during the day. Because of the SAAF's inability to overcome the air dominance, the emphasis shifted to the SA Army and the SAAF's anti-aircraft abilities. The SAAF's air defence was restricted to airfield protection, and the ground forces therefore had no guarantee of a safe air space above the theatre of war. The morale of troops who participated and of leader groups was negatively affected by the result of the hostile air threat. The fact the SADF troops were almost exclusively aware of the hostile air force, without experiencing the presence of the SAAF as well, left them with the perception that the SAAF did not participate in the operation and that they had abandoned them. ${ }^{93}$ Rumours, especially about return dates, also affected the troops negatively from time to time. The long waiting periods, the long periods away from their families, the unavailability of vehicle parts and tropical diseases also harmed the morale of SADF members. $^{94}$

The SADF's Director Infantry stated in his reflection memorandum frankly that, the biggest problems experienced were of a logistic nature. ${ }^{95}$ The head of the SA Army was of the opinion that a slow logistic system and the hostile air dominance restricted the South African forces' freedom to act. ${ }^{96}$ Convoys that left Rundu without a convoy commander, without protection and without communication, among others, contributed to the logistic inefficiency. Some convoys even travelled without a light workplace troop (mechanic), which was the main reason why equipment was left along the road and why the right equipment did not reach the right place. ${ }^{97}$ In the objective memorandum that was compiled on the basis of the reflection reports of Operations Modular, Hooper and Packer, the first and most important objective was therefore that the efficient operational condition of all battle and support vehicles had to be at least $95 \%$ before the start of an operation. $^{98}$ 
The gathering of information/intelligence was not up to standard either. The SADF mostly had to rely on UNITA information, which was more often than not undependable. Dörning, a historian in service of the SADF, therefore understandably concludes that the question is whether the principles (and thus the prerequisites) for a successful attack were followed by own forces in the case of Tumpo and, if this was impossible, why the attacks were nevertheless carried out. ${ }^{99}$

Within a period of approximately two weeks, two failed assaults were launched on Tumpo - every time from the same direction or line of approach. The FAPLA forces were very well entrenched and equipped and also dominated the air. The SADF-UNITA assault, by contrast, was thwarted by among others insufficient intelligence (especially with regard to the second minefield and the acre of death), insufficient military equipment and manpower, insufficient logistic operations and an almost impassable, sandy and densely bushed area. A follow-up article will address Operation Packer (March to April 1988), with particular focus on why the third assault on Tumpo also failed.

\section{Endnotes}

${ }^{1}$ The author is responsible for various articles on Operation Modular: "Die SuidAfrikaanse Weermag en Transgrensoperasie Modulêr, fase 1: Die FAPLAoffensief teen UNITA, Augustus-Oktober 1987'. New Contree 60. November 2010. 43-61; "Die Suid-Afrikaanse Weermag en die 'stryd' om Cuito Cuanavale: Fases 2, 3 en 4 van Operasie Moduler, Oktober-Desember 1987”. New Contree 61. Mei 2011. 31-55; “Operasies Chuva en Modulêr (fase 1): 'n Waardering van die SADF-UNITA-bondgenootskap, Mei tot Oktober 1987'. Historia 57/2. November 2012. 378-415.

2 The name FAPLA is used here as a collective term and also includes the Cuban and Russian allies.

${ }^{3}$ South African National Defence Force Documentation Centre (SANDFDC), Pretoria, JF Huyser collection (JHF), Box 29, File 146: Oorlogsdagboek HK 20 Bde, Vol. 2, 29 November 1987, Series 1; 30 November 1987, Series 1; 1 December 1987, Series 1; 2 December 1987, Series 1; 9 December 1987, Series 2.

${ }^{4}$ J. Geldenhuys, J (compiler)., Ons was daar: Wenners van die oorlog om SuiderAfrika. Pretoria: (Kraal Publishers, Pretoria, ca 2011), p. 415.

5 The 'campaign' comprised Operations Modular, Hooper and Packer. The latter was the 'last phase' and took place during March and April 1988. Each of the operations was characterised by a transitional phase during which conscripted soldiers completed their border duty and were then replaced by conscripted soldiers who were 'inexperienced' in terms of border duty.

${ }^{6}$ Geldenhuys, J. A general's story from an era of war and peace. Johannesburg: Jonathan Ball, 1995, 219. 
${ }^{7}$ SANDFDC, Pretoria, H SADF, Group 4, Box 62, File HSAW/V/305/5: Lesse geleer tydens konvensionele operasies in die westelike subteater. SA Leër, 3 March 1990, A-2.

${ }^{8}$ SANDFDC, Pretoria, JHF, Box 92, File 426: Gesamentlike militêre aksies deur RSA en UNITA magte teen FAPLA magte in die Sesde Militêre Streek van Angola vanaf Desember 1987 tot Maart 1988, 1-2, 4-6; JHF, Box 89, File 419: Hooper Ops/EME, Series 6, 5-6; Series 13, 11-17, Map 1; also see Nortje, P. 32 Battalion: The inside story of South Africa's elite fighting unit. Cape Town: Zebra Press, 2003, 244-245; Nortje, P. The terrible ones: A complete history of 32 Battalion, Vol. 2. Cape Town: Zebra Press, 2012, 1028-1029; Bothma, LJ. Anderkant Cuito: 'n Reisverhaal van die Grensoorlog. Bloemfontein, Author, 2011, 133-134.

${ }^{9}$ SANDFDC, Pretoria, JHF, Box 89, File 419: Hooper Ops/EME, Map 1, Verdedigingsechelons van FAPLA rondom Cuito Cuanavale; Williams, D. On the border: The white South African military experience 1965-1990. Cape Town: Tafelberg, 2008, 106; Bridgland, F. The war for Africa: Twelve months that transformed a continent. Rivonia: Ashanti, 1993, 258.

${ }^{10}$ SANDFDC, Pretoria, JHF, Box 28, File 136: Signal 20 Bde Tactical HQ/4 SAI, 61 Mech Bn, 18 December 1987; JHF, Box 92, File 426: Gesamentlike militêre aksies ..., 2.

${ }^{11}$ SANDFDC, Pretoria, H Army, D Training, Group 45, Box 165, File 309/1, Vol 6: [Nabetragtingsverslag Operasie Hooper], Addendum to Direkteur Infanterie/Direkteur Opleiding, 2 May 1988, Series 8, 7.

12 SANDFDC, Pretoria, JHF, Box 22, File 87: Appendix E to Staff appreciation Op Hooper, Summarised in appreciation for the attack on Cuito-Cuanavale cu 0422, 26 December 1987, E-17.

${ }^{13}$ SANDFDC, Pretoria, JFH, Box 22, File 83: Ops/005/12 Dec 87, Ops/001/17 Dec 87, Ops/003/19 Dec 87, Ops/001[sic]/20 Dec 87, Ops/002/15 Dec 87; JFH, Box 29, File 146: Oorlogsdagboek HQ 20 Bde, Vol. 2, 13 December 1987, Series 1; 14 December 1987, Series 4; JHF, Box 15, File 54, Vol. 4: Ops/547/2 Dec 87, Ops/605/4 Dec 87, Ops/621/5 Dec 87, Ops/638/6 Dec 87; JHF, Box 16, File 56, Vol. 3: Notes Col Oelschig/Brig Louw, Samesprekings met genl Demostenis [sic] op 6 Des 87, 7 December 1987. Also see Zhdarkin, IA. "Cuito Cuanavale: Notes from the trenches". In Shubin, G \& Tokarev, A (eds), Bush war: The road to Cuito Cuanavale, Soviet soldiers' accounts of the Angolan war, Johannesburg: Jacana Media, 2011, 85, 87-91.

${ }^{14}$ SANDFDC, Pretoria, JHF, Box 29, File 142: Ops/17[6]/12 Dec 87; JHF, Box 16, File 56, Vol. 3: Signal report H SAW3/H Army 31 et al., 11 December 1987; JHF, Box 92, File 426: Gesamentlike militêre aksies ..., 16-19.

${ }^{15}$ SANDFDC, Pretoria, JFH, Box 22, File 83: Ops/003/12 Dec 87, Ops/010/13 Dec 87; JFH, Box 29, File 146: Oorlogsdagboek HQ 20 Bde, Vol. 2, 10 December 1987, Series 2; 14 December 1987, Series 1; 15 December 1987, Series 1; 16 December 1987, Series 1; 17 December 1987, Series 1; JHF, Box 89, File 418, Ops Hooper Bronne: 21 December 1987, Series 1; JHF, 
Box 89, File 419: Hooper Ops/EME, Series 69-70, 20-21 December 1987, 71-72.

${ }^{16}$ SANDFDC, Pretoria, JHF, Box 29, File 149: TD plan vir Ops Hooper, ca. 26 December 1987, RSA/UNITA course of action for attack on FAPLA Bdes/positions east of Cuito Cuanavle [sic] River, ca. 26 December 1987, 7; JHF, Box 29, File 150: Ops/007/87, 22 December 1987.

${ }^{17}$ SANDFDC, Pretoria, JHF, Box 22, File 83: Ops/002/21 Dec 87; JHF, Box 23, File 89: Operasie-/Oorlogsdagboek van 20 Brigade Hoofkwartier, Vol. 1, Series 35, 21 December 1987; Series 36, 23 December 1987; JHF, Box 29, File 150/Box 22, File 82: Ops/007/22 Dec 87; JHF, Box 29, File 149: SK Warren SO1 Ops 20 Brigade, Staff appreciation for attack on Cuito Cuanavale Cu 0422, 26 December 1987, 6; JHF, Box 89, File 418, Ops Hooper Bronne: 23 December 1987, Series 1; JHF, Box 92, File 426: Gesamentlike militêre aksies ..., 27, 29, 31.

${ }^{18}$ SANDFDC, Pretoria, JHF, Box 29, File 150/Box 22, File 85; Ops/014/24 Dec 1987; JHF, Box 92, File 426: Gesamentlike militêre aksies ..., 33; JHF, Box 89, File 419: Hooper Ops/EME, Series 93, 24 December 1987, 88.

${ }^{19}$ SANDFDC, Pretoria, JHF, Box 29, File 142: Ops/001/2 Jan 88.

${ }^{20}$ SANDFDC, Pretoria, JHF, Box 22, File 83: Ops/029/31 Dec 87, Ops/476/31 Dec 87; JHF, Box 92, File 426: Gesamentlike militêre aksies ..., 38; JHF, Box 89, File 419: Hooper Ops/EME, Series 104, 105, 107, 26 December 1987, 105, 107-108.

${ }^{21}$ SANDFDC, Pretoria, JHF, Box 22, File 83: Ops/002/21 Dec 87, Ops/008/22 Dec 87, Ops/012/23 Dec 87, Ops/014[sic]/24 Dec 87, Ops/016/25 Dec 87, Ops/008[sic]/26 Dec 87, Ops/001/27 Dec 87, Ops/007/28 Dec 87, Ops/009/29 Dec 87, Ops/010/30 Dec 87; Ops/029/31 Dec 87, JHF, Box 92, File 426: Gesamentlike militêre aksies ..., 27-30, 32; Holt, C. At thy call we did not falter: A frontline account of the 1988 Angolan war, as seen through the eyes of a conscripted soldier. Cape Town: Zebra Press, 2005, 16, 34-35, 42, 44-46, 49, 53-57.

${ }^{22}$ SANDFDC, Pretoria, JHF, Box 22, File 83: Ops/008/22 Dec 87.

${ }^{23}$ SANDFDC, Pretoria, JHF, Box 90, File 420: Hooper ITSA/VY, 26 December 1987, Series 1, 2, 4; JHF, Box 92, File 426: Gesamentlike militêre aksies ..., 40-41.

${ }^{24}$ SANDFDC, Pretoria, JHF, Box 90, File 420: Hooper ITSA/VY, 30 December 1987, Series 1; JHF, Box 92, File 426: Gesamentlike militêre aksies ..., 46; JHF, Box 89, File 419: Hooper Ops/EME, Series 141, 30 December 1987, 125-126.

${ }^{25}$ SANDFDC, Pretoria, JHF, Box 22, File 83: Ops/144/9 Jan 88; JHF, Box 92, File 426: Gesamentlike militêre aksies ..., 48; JHF, Box 89, File 419: Hooper Ops/EME, Series 147, 30 December 1987, 129-130.

${ }^{26}$ SANDFDC, Pretoria, JHF, Box 22, File 83: Ops/009/29 Dec 87, Ops/010/30 Dec 87, Ops/029/31 Dec 1987; JHF, Box 29, File 142: Memorandum, $O p$ beplanning volgens $H$ Leër riglyne, 8 December 1987, 5-6, 9; JHF, Box 22, File 82: KO/004/12 Dec 87; JHF, Box 92, File 426: Gesamentlike militêre 
aksies ..., 48; JHF, Box 89, File 419: Hooper Ops/EME, Series 148, 30 December 1987, 130; Also see Thompson, JH. Dit was oorlog: Van afkak tot bosbefok. Cape Town: Zebra Press, 2007, 200, 202.

${ }^{27}$ Holt op. cit., pp. 51-52, [68F].

${ }^{28}$ SANDFDC, Pretoria, JHF, Box 22, File 83: Ops/0424/B 3 Jan 88; JHF, Box 92, File 426: Gesamentlike militêre aksies ..., 52-53; "Dagboek van luitenant W. Surmon", Jan 1-2. In Williams, D (ed), Op die grens: Wit mans se militêre ervaring 1965-1990, Cape Town: Tafelberg, 2008, 43-44.

${ }^{29}$ SANDFDC, Pretoria, JHF, Box 22, File 83: Ops/047/2 Jan 88; JHF, Box 23, File 89: Operasie-/Oorlogsdagboek van 20 Brigade Hoofkwartier, Vol. 1, Series 49-50, 1 January 1988; Series 53, 2 January 1988; JHF, Box 89, File 418, Ops Hooper Bronne: 2 January 1988, Series 2-4; JHF, Box 90, File 420: Hooper ITSA/VY, 2 January 1987, Series 1, 3-4; JHF, Box 92, File 426: Gesamentlike militêre aksies ..., 53-54; JHF, Box 89, File 419: Hooper Ops/EME, Series 164-167, 2 January 1988, 145-148; Also see Hamann, H. Days of the generals: The untold story of South Africa's apartheid-era military generals. Cape Town: Zebra Press, 2001, 95.

${ }^{30}$ Batley, K (ed). A secret burden: Memories of the Border War by South African soldiers who fought in it. Johannesburg: Jonathan Ball, 2007, 19, 75; Casius, A. “Arno se dagboek." In Geldenhuys, Ons was daar ... op. cit., pp. 369377; also see Feinstein, A. Kopwond: Vergete slagoffers van die Bosoorlog. Cape Town: Tafelberg, 2011.

${ }^{31}$ Holt op. cit., p. 42.

${ }^{32}$ SANDFDC, Pretoria, JHF, Box 22, File 83: Ops/092/5 Jan 88; JHF, Box 92, File 426: Gesamentlike militêre aksies ..., 56-57; JHF, Box 89, File 419: Hooper Ops/EME, Series 172, 174, 2 January 1988, 152-156.

${ }^{33}$ SANDFDC, Pretoria, JHF, Box 22, File 87: Appendix E to Staff appreciation Op Hooper ..., 26 December 1987, E-75-77; JHF, Box 22, File 88: Opsec plan for Op Hooper: 1987 [Enclosure 1 to Appendix E to Staff appreciation $\mathrm{Op}$ Hooper ..., 26 December 1987], I E-6-I E-8.

${ }^{34}$ SANDFDC, Pretoria, JHF, Box 29, File 142: Ops/017/24 Dec 87, Ops/019/24 Dec 87; JHF, Box 16, File 56, Vol. 3: Ops/468 Tactical HQ Rundu/H Army 31 et al., 30 November 1987; Ops 525 Tactical HQ Rundu/H Army et al., 2 December 1987; JHF, Box 90, File 420: Hooper ITSA/VY, 3 January 1988, Series 1; JHF, Box 92, File 426: Gesamentlike militêre aksies ..., 57; JHF, Box 89, File 419: Hooper Ops/EME, Series 175-176, 3 January 1988, 156157; Siebrits, P. “24 Eskader - Per Noctem Per Diem.” In Geldenhuys, Ons was daar ... op. cit., pp. 237-240.

${ }^{35}$ SANDFDC, Pretoria, JHF, Box 22, File 83: Ops/058/3 Jan 88; JHF, Box 90, File 420: Hooper ITSA/VY, 3 January 1988, Series 2, 8A; JHF, Box 92, File 426: Gesamentlike militêre aksies ..., 58-59; JHF, Box 89, File 419: Hooper Ops/EME, Series 178-182, 3 January 1988, 158-161; Siebrits op. cit., p. 240.

${ }^{36}$ SANDFDC, Pretoria, JHF, Box 22, File 83: Ops/092/5 Jan 88, Ops/0441/B 5 Jan 88, Ops/0445/B 6 Jan 88, Ops/099/ 6 Jan 88, Ops/131/8 Jan 88; JHF, Box 
22, File 85: Signal 20 Bde HQ/4 SAI and 61 Mech, 4 January 1988; JHF, Box 92, File 426: Gesamentlike militêre aksies ..., 59-74.

${ }^{37}$ SANDFDC, Pretoria, JHF, Box 29, File 142: Ops/093/9 Jan 88; JHF, Box 89, File 418, Ops Hooper Bronne: 9 January 1988, Series 12; JHF, Box 92, File 426: Gesamentlike militêre aksies ..., 71-72; JHF, Box 89, File 419: Hooper Ops/EME, Series 239, 9 January 1988, 196-197.

${ }^{38}$ SANDFDC, Pretoria, JHF, Box 23, File 89: Operasie-/Oorlogsdagboek van 20 Brigade Hoofkwartier, Vol. 1, Series 90-91, 12 January 1988, Addendum A: Opsomming van hoof gebeure [Tweede aanval op 21 Brigade, 13-14 January 1988], A1; JHF, Box 92, File 426: Gesamentlike militêre aksies ..., 75-79; JHF, Box 89, File 419: Hooper Ops/EME, Series 253-255, 261-263, 266, 268, 270-271, 274, 11-13 January 1988, 207-208, 212-217, 219. [“Dagboek van luitenant W. Surmon"], Jan 1-2. In Williams, Op die grens ... op. cit., p. 44.

${ }^{39}$ SANDFDC, Pretoria, JHF, Box 23, File 89: Operasie-/Oorlogsdagboek van 20 Brigade Hoofkwartier, Vol. 1, Addendum A: Opsomming van hoof gebeure [Tweede aanval op 21 Brigade, 13-14 January 1988], A1-A3; JHF, Box 90, File 420: Hooper ITSA/VY, 13 January 1988, Series 37-38, 13-14 January 1988, Series 9, 14 January 1988, Series 9; JHF, Box 92, File 426:

Gesamentlike militêre aksies ..., 79-82, 84-86; JHF, Box 89, File 419: Hooper Ops/EME, Series 272-273, 282, 286, 288-292, 300, 305-306, 13 14 January 1988, 218, 223, 226-230, 234, 239; Nortje, The terrible ones ... op. cit., p. 1038.

${ }^{40}$ SANDFDC, Pretoria, JHF, Box 22, File 83: Ops/0468/1/B 16 Jan 88; JHF, Box 23, File 89: Operasie-/Oorlogsdagboek van 20 Brigade Hoofkwartier, Vol. 1, Series 96, 14 January 1988; JHF, Box 22, File 86: Hooper, 15 Jan 88; JHF, Box 92, File 426: Gesamentlike militêre aksies ..., 84-87; JHF, Box 89, File 419: Hooper Ops/EME, Series 304, 307-308, 14 January 1988, 236238, 242-243.

${ }^{41}$ SANDFDC, Pretoria, JHF, Box 92, File 426: Gesamentlike militêre aksies ..., 88; JHF, Box 89, File 419: Hooper Ops/EME, Series 309, 14 January 1988, 243-244.

${ }^{42}$ SANDFDC, Pretoria, JHF, Box 22, File 83: Ops/230/17 Jan 88, Ops/241/18 Jan 88; JHF, Box 92, File 426: Gesamentlike militêre aksies ..., 88-90.

${ }^{43}$ SANDFDC, Pretoria, JHF, Box 23, File 89: Operasie-/Oorlogsdagboek van 20 Brigade Hoofkwartier, Vol. 1, Series 104, 18 January 1988; JHF, Box 90, File 420: Hooper ITSA/VY, 18 January 1988, Series 1-4; JHF, Box 92, File 426: Gesamentlike militêre aksies ..., 99; JHF, Box 89, File 419: Hooper Ops/EME, Series 347, 24 January 1988, 276-278.

${ }^{44}$ SANDFDC, Pretoria, JHF, Box 23, File 89: Operasie-/Oorlogsdagboek van 20 Brigade Hoofkwartier, Vol. 1, Series 104, Addendum D [FAPLA herower die stellings van 21 Brigade], 18 January 1988; JHF, Box 92, File 426: Gesamentlike militêre aksies ..., 94; JHF, Box 89, File 419: Hooper Ops/EME, Series 324, 18 January 1988, 262. 
${ }^{45}$ SANDFDC, Pretoria, JHF, Box 92, File 426: Gesamentlike militêre aksies ..., 95; JHF, Box 89, File 419: Hooper Ops/EME, Series 327, 18 January 1988, 265.

${ }^{46}$ SANDFDC, Pretoria, JHF, Box 29, File 142: Ops/157/21 Jan 88; JHF, Box 28, File 136: Ops/001/21/01/88; JHF, Box 89, File 418, Ops Hooper Bronne: 21 January 1988, Series 2; JHF, Box 92, File 426: Gesamentlike militêre aksies ..., 97; JHF, Box 89, File 419: Hooper Ops/EME, Series 336, 21 January 1988, 270-271.

${ }^{47}$ SANDFDC, Pretoria, JHF, Box 22, File 85: Colonel P.S. Fouché, commander 20 brigade, Komops eie magte instruksie, 26 January 1988; JHF, Box 22, File 86: Ops/002/[ca. 12] Dec 87; JHF, Box 67, File 332: UNITA as belangrike teenvoeter vir die Sowjetimperialisme in Afrika; Also see Williams, Op die grens ... op. cit., p. 31.

${ }^{48}$ SANDFDC, Pretoria, JHF, Box 22, File 86: Kapelaansplan, Ops Hooper - 20 Bde, undated, 2.

${ }^{49}$ SANDFDC, Pretoria, JHF, Box 22, File 83: Ops/230/17 Jan 88; JHF, Box 22, File 86: Ops/882/17 Jan 88; JHF, Box 92, File 426: Gesamentlike militêre aksies ..., 91-93; JHF, Box 89, File 419: Hooper Ops/EME, Series 323-324, 17 January 1988, 254-260.

${ }^{50}$ SANDFDC, Pretoria, JHF, Box 22, File 82: Ops/303/24 Jan 88; JHF, Box 92, File 426: Gesamentlike militêre aksies ..., 101-102.

${ }^{51}$ SANDFDC, Pretoria, JHF, Box 23, File 89: Operasie-/Oorlogsdagboek van 20 Brigade Hoofkwartier, Vol. 2, Series 16, 28 January 1988; JHF, Box 92, File 426: Gesamentlike militêre aksies ..., 106-107; JHF, Box 89, File 419: Hooper Ops/EME, Series 369, 28 January 1988, 297-300.

52 SANDFDC, Pretoria, JHF, Box 22, File 83: Ops/273/20 Jan 88; JHF, Box 92, File 426: Gesamentlike militêre aksies ..., 103, 105.

${ }^{53}$ SANDFDC, Pretoria, JHF, Box 22, File 83: Ops/079/4 Jan 88, Ops/0447/B 7 Jan 88, Ops/110/7 Jan 88, Ops/151/10 Jan 88; Ops/241/18 Jan 88; Ops/273/20 Jan 88, Ops/378/29 Jan 88, Ops/278/21 Jan 88, Ops/397/30 Jan 88, Ops/579/8 Feb 88.

${ }^{54}$ SANDFDC, Pretoria, JHF, Box 22, File 83: Ops/009/29 Dec 87, Ops/011/3 Jan 88, Ops/063/3 Jan 88, Ops/110/7 Jan 88; Ops/131/8 Jan 88; Ops/0456/1/B 9 Jan 88, Ops/305/24 Jan 88, Ops/541/5 Feb 88, Ops/542/5 Feb 88; JHF, Box 23, File 89: Operasie-/Oorlogsdagboek van 20 Brigade Hoofkwartier, Vol. 2, Series 41, 7 Februarie 1988.

55 SANDFDC, Pretoria, JHF, Box 22, File 83: Ops/0447/B 7 Jan 88.

${ }^{56}$ SANDFDC, Pretoria, JHF, Box 22, File 82: Ops/436/2 Feb 88; JHF, Box 27, File 122: Onderhoud met kmdt A. Brosens, TSO Vggp Charlie op 5 Februarie 1988, 8-9; JHF, Box 89, File 418, Ops Hooper Bronne: 2 Februarie 1988, Series 4; JHF, Box 92, File 426: Gesamentlike militêre aksies ..., 108-109, 112; JHF, Box 89, File 419: Hooper Ops/EME, Series 371, 390, 28 January, 2 February 1988, 303-304, 314-315.

${ }^{57}$ Standing orders were issued in January 1988 already, among others that commanders should do regular inspections to ensure that SADF members were living hygienically. Furthermore, all commanders, together with 
medical officers, were personally responsible for seeing to it that all members took malaria medication twice a week and that a "malaria register", with signatures, was kept up to date. Upon closer investigation, however, it was found that some SADF personnel did not follow the prescriptions and that they, for instance, took only one pill a week, or one pill every 14 days. Strict supervision, which among others included pill parades, was therefore enforced to ensure that all members took two malaria pills twice a week. See SANDFDC, Pretoria, JHF, Box 22, File 85:

Eenheidstaandeorder deur kmdt M.G. Schoeman SAIK bevelvoerder brigade administrasie gebied, Mavinga, January 1988, 10-11; JHF, Box 22, File 83: Ops/0415/1/B Jan 88; JHF, Box 23, File 89: Operasie-/Oorlogsdagboek van 20 Brigade Hoofkwartier, Vol. 1, Series 45, 31 December 1987; JHF, Box 29, File 142: Ops/038/29 Dec 87, Ops/047/30 Dec 88.

${ }^{58}$ SANDFDC, Pretoria, JHF, Box 22, File 83: Ops/505/3 Feb 88, Ops/527/4 Feb 88; Ops/541/5 Feb 88; JHF, Box 22, File 85: Ops/518/4 Feb 88; JHF, Box 29, File 142: Ops/010/23 Dec 87; JHF, Box 28, File 137: Det/669/4 Feb 88; JHF, Box 22, File 86: Hooper, 29 Jan 88, 31 Jan 88, 1 Feb 88; JHF, Box 27, File 122: Onderhoud met kmdt A. Brosens, TSO Vggp Charlie op 5 Februarie 1988, File 418, Ops Hooper Bronne: 4 February 1988, Series 6; JHF, Box 92, File 426: Gesamentlike militêre aksies ..., 113; JHF, Box 89, File 419: Hooper Ops/EME, Series 394-395, 3-4 Februarie 1988, 316-317.

${ }^{59}$ SANDFDC, Pretoria, JHF, Box 22, File 83: Ops/0447/B 7 Jan 88, Ops/110/7 Jan 88; JHF, Box 22, File 82: Ops/406/31 Jan 88; JHF, Box 22, File 85: Ops/518/4 Feb 88.

${ }^{60}$ Agreement does not exist about the illness of the two commanders. F Bridgland and H Heitman, for example, report that commanders Malan and Liebenberg both had 'hepatitis', while W Dörning (Historian, SADF) identifies jaundice as the illness in both cases. In the war journal of 20 Brigade it is mentioned that Malan contracted jaundice, but no reason is given why Koos Liebenberg had to be replaced. See Bridgland op. cit., p. 272; Heitmann, H-R. War in Angola: The final South African phase. Gibraltar: Ashanti, 1990, 215-216; SANDFDC, Pretoria, JHF, Box 92, File 426: Gesamentlike militêre aksies ..., 95; JHF, Box 23, File 89: Operasie-/Oorlogsdagboek van 20 Brigade Hoofkwartier, Vol. 1, Series 107, 18 January 1988.

${ }^{61}$ SANDFDC, Pretoria, JHF, Box 23, File 89: Operasie-/Oorlogsdagboek van 20 Brigade Hoofkwartier, Vol. 1, Series 107, 18 January 1988; See SANDFDC, Pretoria, JHF, Box 23, File 89: Operasie-/Oorlogsdagboek van 20 Brigade Hoofkwartier, Vol. 2, Series 151, 24 Februarie 1988; JHF, Box 22, File 82: Ops/519/4 Feb 88; JHF, Box 92, File 426: Gesamentlike militêre aksies ..., 118.

${ }^{62}$ SANDFDC, Pretoria, JHF, Box 92, File 426: Gesamentlike militêre aksies ..., 109, 116-118.

${ }^{63}$ SANDFDC, Pretoria, JHF, Box 89, File 419: Hooper Ops/EME, Map 7, Aanvalle op 59 Bde and 21 Bde op 14 Feb [1988]; Williams, On the border ... op. cit., p. 103; Bridgland op. cit., p. 275. 
${ }^{64}$ SANDFDC, Pretoria, JHF, Box 28, File 136: Ops/281/1 Feb 88; JHF, Box 90, File 420: Hooper ITSA/VY, 14 Februarie 1988, Series 2, 5; JHF, Box 92, File 426: Gesamentlike militêre aksies ..., 121-124.

${ }^{65}$ SANDFDC, Pretoria, JHF, Box 23, File 89: Operasie-/Oorlogsdagboek van 20 Brigade Hoofkwartier, Vol. 2, Series 65-69, 78, 81, 14 February 1988, Addendum E, Rekonstruksie van the aanval op 59 Bde; JHF, Box 28, File 137: Ops/669/15 Feb 88, Ops/695/16 Feb 88; JHF, Box 92, File 426: Gesamentlike militêre aksies ..., 124-126, 129-130.

${ }^{66}$ SANDFDC, Pretoria, JHF, Box 23, File 89: Operasie-/Oorlogsdagboek van 20 Brigade Hoofkwartier, Vol. 2, Series 73, 91, 106, 110, 14 February 1988, Addendum E, Rekonstruksie van the aanval op 59 Bde; JHF, Box 28, File 137: Ops/669/15 Feb 88, Ops/695/16 Feb 88; JHF, Box 92, File 426:

Gesamentlike militêre aksies ..., 127-129; Also see Dreyer, R. Namibia and Southern Africa: Regional dynamics of decolonization 1945-90. London: Kegan Paul International, 1994, 170.

${ }^{67}$ SANDFDC, Pretoria, JHF, Box 92, File 426: Gesamentlike militêre aksies ..., 130; JHF, Box 89, File 419: Hooper Ops/EME, Series 486-487, 15 February 1988, 369-370A.

${ }^{68}$ SANDFDC, Pretoria, JHF, Box 23, File 89: Operasie-/Oorlogsdagboek van 20 Brigade Hoofkwartier, Vol. 2, Series 113, 14 February 1988; JHF, Box 28, File 137: Ops/669/15 Feb 88.

${ }^{69}$ SANDFDC, Pretoria, JHF, Box 92, File 426: Gesamentlike militêre aksies ..., 129, 131; JHF, Box 89, File 419: Hooper Ops/EME, Series 475, 14 February 1988, 365-366.

${ }^{70}$ SANDFDC, Pretoria, JHF, Box 92, File 426: Gesamentlike militêre aksies ..., 136-137; JHF, Box 89, File 419: Hooper Ops/EME, Series 512-513, 515516, 20 February 1988, 384-388.

${ }^{71}$ SANDFDC, Pretoria, JHF, Box 92, File 426: Gesamentlike militêre aksies ..., 137; JHF, Box 89, File 419: Hooper Ops/EME, Series 518-519, 20 February 1988, 389-390.

72 SANDFDC, Pretoria, JHF, Box 23, File 89: Operasie-/Oorlogsdagboek van 20 Brigade Hoofkwartier, Vol. 2, Series 124, 17 February 1988; Series 130, 19 February 1988; Series 140, 21 February 1988; Series 145, 22 February 1988; JHF, Box 92, File 426: Gesamentlike militêre aksies ..., 132-133.

${ }^{73}$ SANDFDC, Pretoria, JHF, Box 23, File 89: Operasie-/Oorlogsdagboek van 20 Brigade Hoofkwartier, Vol. 2, Series 135, 141; JHF, Box 22, File 82: Ops/745/21 Feb 88; JHF, Box 28, File 137: Ops 245/21 Feb 88, Ops/751/21 Feb 88.

${ }^{74}$ SANDFDC, Pretoria, JHF, Box 92, File 426: Gesamentlike militêre aksies ..., 140; JHF, Box 89, File 419: Hooper Ops/EME, Series 531, 22 February 1988, 397.

${ }^{75}$ SANDFDC, Pretoria, JHF, Box 23, File 89: Operasie-/Oorlogsdagboek van 20 Brigade Hoofkwartier, Vol. 2, Series 150; JHF, Box 92, File 426: Gesamentlike militêre aksies ..., 143; JHF, Box 89, File 419: Hooper Ops/EME, Series 537, 24 February 1988, 403-405. 
${ }^{76}$ SANDFDC, Pretoria, JHF, Box 23, File 89: Operasie-/Oorlogsdagboek van 20 Brigade Hoofkwartier, Vol. 2, Series 151, 24 February 1988.

${ }^{77}$ SANDFDC, Pretoria, JHF, Box 29, File 142: Ops/384/20 Feb 88.

${ }^{78}$ SANDFDC, Pretoria, JHF, Box 23, File 89: Operasie-/Oorlogsdagboek van 20 Brigade Hoofkwartier, Vol. 2, Series 151-206; JHF, Box 28, File 139: Ops/412/26 Feb 1988; JHF, Box 90, File 420: Hooper ITSA/VY, 25 February 1988, Series 5, 7, 23; JHF, Box 92, File 426: Gesamentlike militêre aksies ..., 143-147; Also see Nortje, The terrible ones ... op. cit., pp. 10411044; Norval, M. Death in the desert: The Namibian tragedy. Washington, DC: Selous Foundation Press, 1989, 223.

${ }^{79}$ SANDFDC, Pretoria, JHF, Box 23, File 89: Operasie-/Oorlogsdagboek van 20 Brigade Hoofkwartier, Vol. 2, Series 211; JHF, Box 92, File 426: Gesamentlike militêre aksies ..., 148-149; JHF, Box 89, File 419: Hooper Ops/EME, Series 565, 567-568, 570-571, 25 February 1988, 419-422.

${ }^{80}$ SANDFDC, Pretoria, JHF, Box 28, File 137: Seinberig Sitrap vir tydperk 251800B tot 261800B Feb 88, 26 February 1988.

${ }^{81}$ SANDFDC, Pretoria, JHF, Box 92, File 426: Gesamentlike militêre aksies ..., 149; JHF, Box 89, File 419: Hooper Ops/EME, Series 572, 25 February 1988, 423, 425.

${ }^{82}$ SANDFDC, Pretoria, JHF, Box 92, File 426: Gesamentlike militêre aksies ..., $150-152,156$.

${ }^{83}$ SANDFDC, Pretoria, JHF, Box 22, File 85: Ops/144/27 Feb 88, Ops/116/23 Feb 88, Ops/734/19 Feb 88, Ops/317/25 Jan 88; JHF, Box 92, File 426: Gesamentlike militêre aksies ..., 152-156; JHF, Box 89, File 419: Hooper Ops/EME, Series 588, 590, 28 February 1988, 433-436.

${ }^{84}$ SANDFDC, Pretoria, JHF, Box 23, File 89: Operasie-/Oorlogsdagboek van 20 Brigade Hoofkwartier, Vol. 2, Series 228, 230-232, Addendum [F] "Radio log-opsomming van aanval op Tumpo $29 \mathrm{Feb} / 1 \mathrm{Mrt”}$; JHF, Box 28, File 137: Ops/838/29 Feb 88; JHF, Box 89, File 419: Hooper Ops/EME, Series 599-601, 28 February 1988, 446-448.

${ }^{85}$ SANDFDC, Pretoria, JHF, Box 23, File 89: Operasie-/Oorlogsdagboek van 20 Brigade Hoofkwartier, Vol. 2, Series 235, 238-239, 245, 259, 261-262, 269; JHF, Box 28, File 137: Ops/852/88 1 Mar 88; JHF, Box 89, File 418, Ops Hooper Bronne: Nabetragtingsverslag: Aanval op 1 Mrt 88, paragraphs 1112, 14, 17, 19-21, 22, 24; JHF, Box 90, File 420: Hooper ITSA/VY, 1 March 1988, Series 3, 7, 9-10, 12; JHF, Box 92, File 426: Gesamentlike militêre aksies ..., 158-162.

${ }^{86}$ SANDFDC, Pretoria, JHF, Box 23, File 89: Operasie-/Oorlogsdagboek van 20 Brigade Hoofkwartier, Vol. 2, Series 267-271, Addendum [F] "Radio logopsomming van aanval op Tumpo $29 \mathrm{Feb} / 1 \mathrm{Mrt}$ ”; JHF, Box 28, File 137: Ops/852/88 1 Mar 88; JHF, Box 89, File 418: Ops Hooper Bronne: Nabetragtingsverslag: Aanval op 1 Mrt 88, paragraphs 7, 28-30; JHF, Box 92, File 426: Gesamentlike militêre aksies ..., 162-163; JHF, Box 89, File 419: Hooper Ops/EME, Series 624, 626-631, 1 March 1988, 459-463; also 
see Breytenbach, J. The Buffalo soldiers: The story of South Africa's 32Battalion 1975-1993 ( $2^{\text {nd }}$ ed). Alberton: Galago, 2004, 307.

${ }^{87}$ SANDFDC, Pretoria, JHF, Box 23, File 89: Operasie-/Oorlogsdagboek van 20 Brigade Hoofkwartier, Vol. 2, Series 271, 275; JHF, Box 28, File 137: Ops/890/3 Mar 88.

${ }^{88}$ SANDFDC, Pretoria, JHF, Box 23, File 89: Operasie-/Oorlogsdagboek van 20 Brigade Hoofkwartier, Vol. 2, "Nabetragtingsverslag: Aanval op Tumpo 1 Mrt 88", paragraph 32; JHF, Box 92, File 426: Gesamentlike militêre aksies ..., 164-165; JHF, Box 89, File 419: Hooper Ops/EME, Series 637, 640, 642, 1 March 1988, 466-470; also see Williams, On the border ... op. cit., pp. 104-105.

${ }^{89}$ SANDFDC, Pretoria, JHF, Box 23, File 89: Operasie-/Oorlogsdagboek van 20 Brigade Hoofkwartier, Vol. 2, Series 277, 281, 284, 302, 308-309; JHF, Box 22, File 82: Ops/862/3 Mar 88, Doelwitplan: Aksies tydens tydperk van oorhandiging/oorname tussen Bdes [4 March 1988]; JHF, Box 28, File 137: Ops/883/4 Mar 88, Ops/891/88 5 Mar 88, Ops/892/6 Mar 88, Ops/899/7 Mar 88, Ops/952/12 Mar 88; JHF, Box 28, File 139: Ops/457/3 Mar 1988, Ops/467/4 Mar 1988, Ops/510/10 Mar 1988; JHF, Box 28, File 141: 4 SAI Bewegingsinstruksie, 4 March 1988; JHF, Box 92, File 426: Gesamentlike militêre aksies ..., 166, 168-169, 171.

90 “Crocker kuier en die koeëls klap”. Beeld. 28 January 1988. 2; ““Operational conditions' in SA withdrawal". Pretoria News. 17 February 1988. 2; also see Arnold, G. Wars in the Third World since 1945. London: Cassell, 1991, 344-345.

${ }^{91}$ SANDFDC, Pretoria, JHF, Box 27, File 122: Onderhoud met Kol Roeland [sic] de Fries op 16 February 1988 by die SA Leërkollege in Voortrekkerhoogte, 14.

92 SANDFDC, Pretoria, H Leër, D Opl, Group 45, Box 165, File 309/1, Vol. 6: Memorandum, Direkteur KDK \& Direkteur Spys/Direkteur Opleiding, 31 March 1988, 2.1; Group 45, Box 165, File 309/1, Vol. 6: [Nabetragtingsverslag Operasie Hooper], Addendum tot Memorandum Direkteur Infanterie/Direkteur Opleiding, 2 May 1988, Series 21, 37, pp. 10, 17.

${ }^{93}$ SANDFDC, Pretoria, H SADF, Group 4, Box 62, File HSAW/V/305/5: Lesse geleer tydens konvensionele operasiess in die westelike subteater. SA Leër, 3 March 1990, 2-1, 2-13, 2-19, 5-1, 5-10.

${ }^{94}$ SANDFDC, Pretoria, H SADF, Group 4, Box 62, File HSAW/V/305/5: Lesse geleer tydens konvensionele operasies in die westelike subteater. SA Leër, 3 March 1990, 2-19; H Leër, D Opl, Group 45, Box 165, File 309/1, Vol. 6: [Nabetragtingsverslag Operasie Hooper], Addendum tot Direkteur Infanterie/Direkteur Opleiding, 2 May 1988, Series 6, p. 4.

95 SANDFDC, Pretoria, H Leër, D Opl, Group 45, Box 165, File 309/1, Vol. 6: [Nabetragtingsverslag Operasie Hooper], Addendum tot Direkteur Infanterie/Direkteur Opleiding, 2 May 1988, Series 38, p. 17. 
${ }^{96}$ SANDFDC, Pretoria, H SADF, Group 4, Box 62, File HSAW/V/305/5: Lesse geleer tydens konvensionele operasies in die westelike subteater. SA Leër, 3 March 1990, 2-1.

${ }^{97}$ SANDFDC, Pretoria, H Leër, D Opl, Group 45, Box 165, File 309/1, Vol. 6: [Nabetragtingsverslag Operasie Hooper], Addendum tot Direkteur Infanterie/Direkteur Opleiding, 2 May 1988, Series 34, p. 15.

${ }^{98}$ SANDFDC, Pretoria, H Leër, D Opl, Group 45, Box 165, File 309/1, Vol. 7: Doelwitte wat voortspruit uit Ops Modulêr [sic], Hooper en Packer: Nabetragting, Series 1, Addendum to Letter Director Technical Services/Director Training, 5 December 1998.

${ }^{99}$ SANDFDC, Pretoria, JHF, Box 92, File 426: Gesamentlike militêre aksies ..., 173. 